\title{
ANALISIS ANGKUTAN SEDIMEN DASAR SUNGAI CIBEET DENGAN HEC-RAS DAN UJI LABORATORIUM
}

\author{
Ivan Andrian' ${ }^{1}$ dan Wati A. Pranoto ${ }^{2}$ \\ ${ }^{1}$ Program Studi Sarjana Teknik Sipil, Universitas Tarumanagara, Jl. Letjen S. Parman No.1 Jakarta \\ Email: ivan.325150061@stu.untar.ac.id \\ ${ }^{2}$ Program Studi Magister Teknik Sipil, Universitas Tarumanagara, Jl. Letjen S. Parman No.1 Jakarta \\ Email: watip@ft.untar.ac.id
}

Masuk: 20-01-2020, revisi: 05-02-2020, diterima untuk diterbitkan: 06-02-2020

\begin{abstract}
Cibeet River is a tributary river of the Citarum River. Length of the Cibeet River is $101 \mathrm{~km}$ with its upstream located on Lemo Mountain and downstream on the Citarum River. This river carries sediment to the Citarum River and is one of the largest supplier of sediment to the Citarum River. Research The Cibeet River sediment transport is only bedload sediment transport. Sediment transport research is carried out by laboratory testing and calculation by HEC-RAS. Laboratory testing is carried out with a circular flume. At HEC-RAS, the method used is Engelund-Hansen, Meyer-Peter and Muller, and Yang. The results of sediment transport with the Meyer-Peter and Muller method are the closest to the results of laboratory testing, between $24.54 \%$ to $50.25 \%$ depends on the flow of water.
\end{abstract}

Keywords: River; Transport; Sediment; HEC-RAS

\begin{abstract}
ABSTRAK
Sungai Cibeet merupakan anak Sungai Citarum. Panjang Sungai Cibeet $101 \mathrm{~km}$ dengan hulu berada di Gunung Lemo dan hilir di Sungai Citarum. Sungai ini membawa sedimen ke Sungai Citarum dan salah satu penyumbang sedimen terbesar ke Sungai Citarum. Penelitian Angkutan sedimen Sungai Cibeet dibatasi hanya pada sedimen dasar. Penelitian angkutan sedimen dilakukan dengan pengujian laboratorium dan perhitungan dengan HEC-RAS. Pengujian laboratorium dilakukan dengan alat circular flume. Pada HEC-RAS, metode yang digunakan adalah Engelund-Hansen, Meyer-Peter and Muller, dan Yang. Hasil angkutan sedimen dengan metode Meyer-Peter and Muller paling mendekati dengan hasil pengujian laboratorium. Perbedaan rata-rata yang didapat antara $24,54 \%$ hingga 50,25\% tergantung pada debit alirannya.
\end{abstract}

Kata kunci: Sungai; Angkutan; Sedimen; HEC-RAS

\section{PENDAHULUAN}

\section{Latar belakang}

Sungai Cibeet terletak di Jawa Barat, tepatnya di daerah Cianjur sampai Karawang. Sungai Cibeet merupakan anak sungai dari Sungai Citarum. Pada awalnya, sungai ini bernama Tjitaroem Twee Rivier atau Sungai Citarum Dua dan berubah nama menjadi Sungai Cileog. Hulu Sungai Cibeet terletak di Gunung Lemo, Kabupaten Cianjur dan bergerak ke utara menuju hilir yang terletak di Sungai Citarum. Sungai ini memiliki panjang 101 kilometer dan merupakan salah satu sungai pemasok air ke saluran irigasi Tarum Barat atau Kalimalang.

Air yang mengalir di Sungai Cibeet tidak hanya air, melainkan membawa material dan partikel lainnya. Material dan partikel ini berasal dari hasil erosi pada dinding dan dasar sungai yang dilewati aliran dari hulu hingga menuju hilir. Sebagian material dan partikel akan mengendap ke dasar sungai akibat proses sedimentasi dan sebagian lagi akan mengalir ke sungai utama, yaitu Sungai Citarum. Endapan ini banyak terjadi di sekitar hilir sungai dan akhirnya menghambat laju aliran tersebut. Ada beberapa faktor yang menentukan angkutan sedimen pada sungai, yaitu kecepatan aliran, debit, bentuk penampang dan sebagainya.

Pada program HEC-RAS tersedia beberapa metode untuk menghitung angkutan sedimen, diantaranya ada metode Ackers-White, Yang, Engelund-Hansen, Meyer-Peter and Muller, Laursen, dan Toffaleti. Dari beberapa metode yang tersedia, dipakai 3 metode yaitu Engelund-Hansen, Meyer-Peter and Muller, dan Yang. Pada penelitian ini, digunakan program HEC-RAS untuk memprediksi besar angkutan sedimen pada Sungai Cibeet dengan beberapa 
metode yang telah disebutkan. Untuk mendapat hasil uji laboratorium, pemodelan angkutan sedimen ini dibuat pada alat circular flume.

\section{Rumusan masalah}

1. Berapa besar angkutan sedimen yang didapat saat pengujian di laboratorium?

2. Berapa besar angkutan sedimen yang didapat melalui program HEC-RAS?

3. Bagaimana perbandingan hasil antara metode perhitungan dari program HEC-RAS dan pengujian di laboratorium?

\section{Maksud dan tujuan penelitian}

Maksud dari penelitian ini adalah untuk mengukur dan mengetahui seberapa besar angkutan sedimen yang dibawa Sungai Cibeet dengan cara pemodelan pada alat circular flume berdasarkan pengujian laboratorium, dan program HEC-RAS dengan metode Engelund-Hansen, Meyer-Peter and Muller, dan Yang.

Tujuan dari penelitian ini adalah untuk mengetahui keakuratan dari ketiga metode yang dipakai dalam program HEC-RAS. Hasil dari metode ini juga akan dibandingkan dengan hasil pengujian laboratorium yang akan dilaksanakan di Laboratorium Hidrolika Universitas Tarumanagara.

\section{Analisa saringan}

Analisa saringan umumnya dipakai untuk menentukan ukuran butiran sedimen kasar, seperti kerikil dan pasir. Cara kerja analisa saringan ini adalah dengan mengayak butiran sedimen di saringan yang sudah disusun, dimana pada susunan teratas adalah saringan dengan lubang terbesar dan yang paling bawah adalah saringan dengan lubang terkecil, biasanya saringan 200. Untuk menentukan butiran dengan diameter yang lolos saringan 200, digunakan hidrometer. Rumus yang digunakan dalam menentukan persentase pasir adalah (Sandjaja, 2015):

$$
\begin{array}{r}
\% \text { Retained }=\frac{\mathrm{W} \text { Retained }}{\mathrm{W} \text { Total }} \times 100 \% \\
\% \text { Passing }=100-\Sigma \% \text { Retained }
\end{array}
$$

Dimana W Retained = Berat pasir yang tertinggal pada tiap saringan, \% Retained $=$ persentase tertahan butiran, $\%$ Passing = persentase butiran yang lolos saringan.

\section{Angkutan sedimen dasar}

Angkutan sedimen dasar adalah partikel-partikel kasar yang bergerak sepanjang dasar sungai dan gerakannya tidak pernah lepas dari dasar sungai. Partikel ini bergerak sampai jarak tertentu, bahkan sampai di bagian muara sungai (Yang, 1996). Berikut ini adalah rumus untuk menghitung debit angkutan sedimen dasar:

$$
\begin{gathered}
\mathrm{Q}=\mathrm{v} \times \mathrm{B} \times \mathrm{H} \\
\mathrm{Qb}=\mathrm{Q} \times(\mathrm{Ct} / 1000 / \mathrm{B})
\end{gathered}
$$

Dengan $\mathrm{Ct}=$ Konsentrasi angkutan sedimen $(\mathrm{ppm}), \mathrm{Q}=$ Debit air $\left(\mathrm{m}^{3} / \mathrm{s}\right), \quad \mathrm{v}=\operatorname{Kecepatan}$ air $(\mathrm{m} / \mathrm{s})$, $\mathrm{B}=$ Lebar saluran (m), H= Tinggi air (m), Qb= Angkutan sedimen dasar (kg/m.s).

\section{Program HEC-RAS}

HEC-RAS software (Hydrologic Engineering Center-River Analysis System) merupakan program yang digunakan untuk menganalisa hidrolik sungai satu dimensi. Program HEC-RAS pertama kali dirilis tahun 1995, dimana pada awal kemunculannya digunakan sebagai perhitungan profil permukaan air untuk aliran tetap satu dimensi. Saat ini, HEC-RAS memiliki kemampuan memodelkan sistem sungai secara sederhana hingga kompleks seperti struktur hidrolik (gorong-gorong, jembatan, dan lainnya). (Brunner, 2005)

Untuk perhitungan angkutan sedimen, HEC-RAS dapat melakukan pemodelan penampang untuk mendapat kapasitas angkutan sedimen. Ada beberapa metode yang disediakan HEC-RAS untuk perhitungan angkutan sedimen, diantaranya Ackers-White; Engelund-Hansen; Laursen (dengan modifikasi Copeland); Meyer-Peter and Muller; Toffaleti; dan Yang (untuk pasir dan kerikil). (Brunner,2016) 


\section{METODOLOGI PENELITIAN}

Melakukan pengujian laboratorium untuk mendapatkan hasil dari angkutan sedimen Sungai Cibeet. Setelah mendapatkan besar angkutan sedimen, dilakukan analisis data dari hasil laboratorium lalu akan dibandingkan dengan analisis data menggunakan metode Engelund-Hansen, Meyer-Peter and Muller, dan Yang. Analisis data ini dilakukan dengan cara perhitungan melalui program HEC-RAS.

Hasil yang didapat dari analisis data akan dibuat kesimpulan untuk mengetahui seberapa besar angkutan sedimen pada Sungai Cibeet dan seberapa akurat metode yang dipakai pada program HEC-RAS dalam menentukan prediksi angkutan sedimen. Setelah itu membuat saran untuk penelitan selanjutnya, baik dalam pengujian maupun dalam pengolahan data HEC-RAS.

\section{HASIL DAN PEMBAHASAN}

\section{Analisa saringan}

Tabel 1 menjelaskan hasil analisa saringan pada sampel Sungai Cibeet. Dari hasil yang didapat menunjukkan bahwa ukuran pasir yang mendominasi sampel sedimen Sungai Cibeet adalah ukuran $0.25 \mathrm{~mm}$.

Tabel 1. Analisa saringan

\begin{tabular}{cccccc}
\hline No. & Sieve No & $\mathrm{D}(\mathrm{mm})$ & Wt. retained & \% retained & $\%$ passsing \\
\hline 1 & 4 & 4,75 & 3,9 & $0,780 \%$ & $99,220 \%$ \\
2 & 10 & 2 & 6,2 & $1,246 \%$ & $97,974 \%$ \\
3 & 20 & 0,85 & 24,9 & $4,986 \%$ & $92,989 \%$ \\
4 & 40 & 0,425 & 100,3 & $20,066 \%$ & $72,923 \%$ \\
5 & 60 & 0,25 & 183,3 & $36,666 \%$ & $36,257 \%$ \\
6 & 140 & 0,106 & 56,8 & $11,366 \%$ & $24,891 \%$ \\
7 & 200 & 0,075 & 3,8 & $0,766 \%$ & $24,126 \%$ \\
8 & pan & - & 0,8 & $0,166 \%$ & $23,960 \%$ \\
& sum & & 380 & & \\
\hline
\end{tabular}

\section{Kecepatan kritis}

Pada tabel 2 adalah rangkuman hasil kecepatan kritis pada pengujian yang dilakukan di Laboratorium Hidrolika. Hasil yang didapat menunjukkan bahwa kedalaman tidak mempengaruhi hasil kecepatan kritis pada sampel tersebut. Hasil kecepatan kritis rata-rata pada pengujian dapat dilihat pada gambar 1.

Tabel 2. Hasil Kecepatan kritis

\begin{tabular}{cccc}
\hline \multicolumn{4}{c}{ Perbandingan Kecepatan Kritis $(\mathrm{m} / \mathrm{s})$} \\
\hline Depth & Sampel 1 & Sampel 2 & Sampel 3 \\
\hline 0 & 0,176 & 0,174 & 0,155 \\
-3 & 0,161 & 0,171 & 0,161 \\
-6 & 0,177 & 0,150 & 0,156 \\
-9 & 0,168 & 0,161 & 0,163 \\
-12 & 0,171 & 0,155 & 0,166 \\
\hline
\end{tabular}




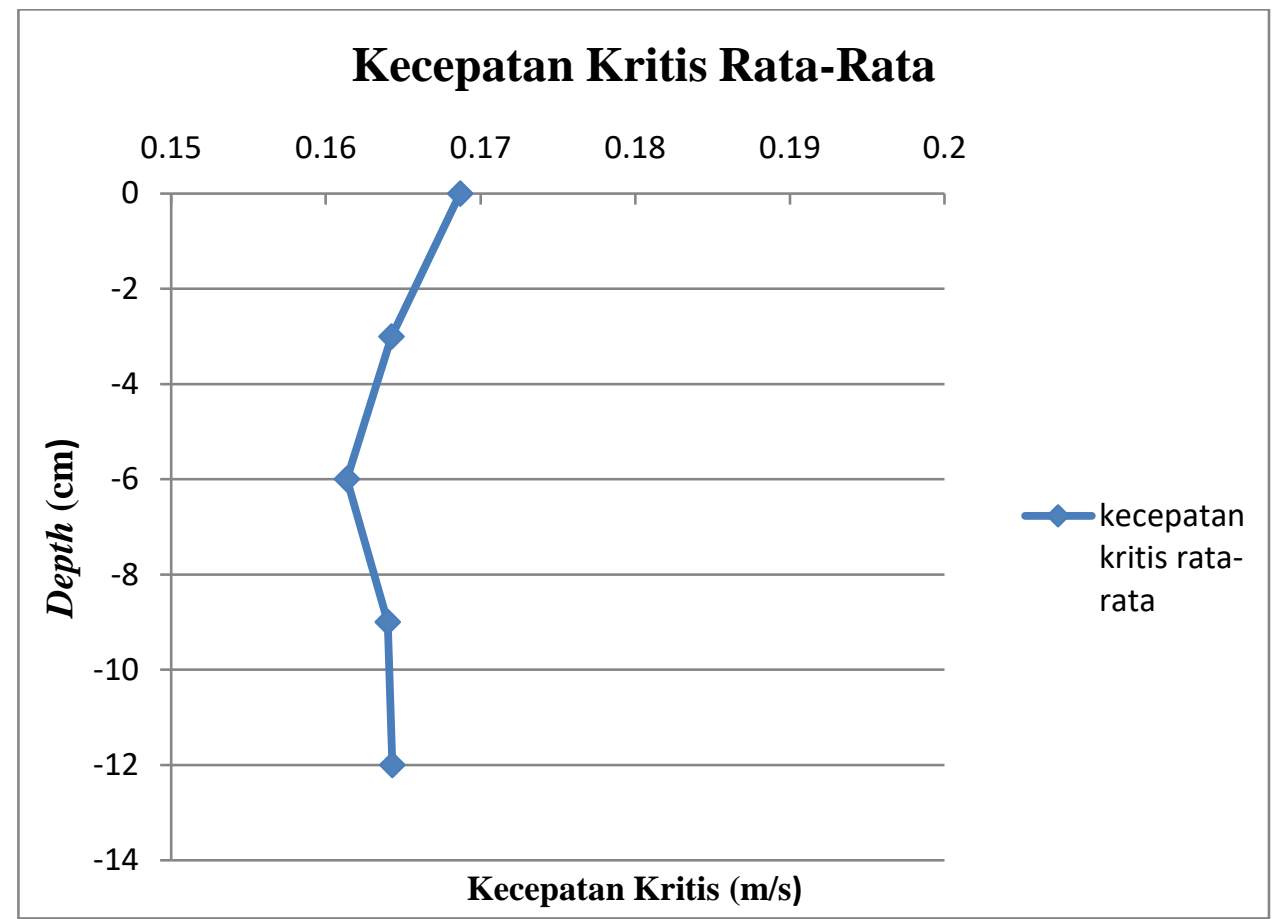

Gambar 1. Grafik perbandingan kecepatan kritis rata-rata

\section{Berat jenis}

Pengambilan berat jenis sedimen dilakukan pada bagian permukaan sampel. Hasil yang didapatkan dari perhitungan ini adalah berat jenis sampel basah dan berat jenis sampel kering. Pada tabel 3 dan tabel 4 adalah rangkuman dari berat jenis sedimen yang didapat dari pengujian:

Tabel 3. Hasil berat jenis basah

\begin{tabular}{ccc}
\hline & Perbandingan Sampel Berat Jenis Basah & \\
\hline Sampel & $\mathrm{BJ}\left(\mathrm{gr} / \mathrm{cm}^{3}\right)$ & Berat Jenis Rata-Rata \\
\hline \multirow{2}{*}{1} & 1,488 & 1,484 \\
& 1,489 & \\
2 & 1,474 & 1,451 \\
& 1,471 & \\
& 1,454 & 1,513 \\
& 1,426 & \\
& 1,523 & \\
\end{tabular}

Tabel 4. Hasil berat jenis kering

\begin{tabular}{ccc}
\hline \multicolumn{3}{c}{ Perbandingan Sampel Berat Jenis Kering } \\
\hline Sampel & $\mathrm{BJ}\left(\mathrm{gr} / \mathrm{cm}^{3}\right)$ & \\
\hline 1 & 1,075 & \\
& 1,085 & 1,076 \\
& 1,069 & \\
2 & 1,124 & 1,106 \\
& 1,102 & \\
3 & 1,092 & \\
& 1,102 & 1,101 \\
& 1,072 & \\
& 1,131 & \\
\hline
\end{tabular}




\section{Hasil penelitian}

Pada gambar 2 menunjukkan bahwa kecepatan mempengaruhi konsentrasi sedimen, dimana semakin besar kecepatan, maka konsentrasi sedimen yang didapat semakin besar.

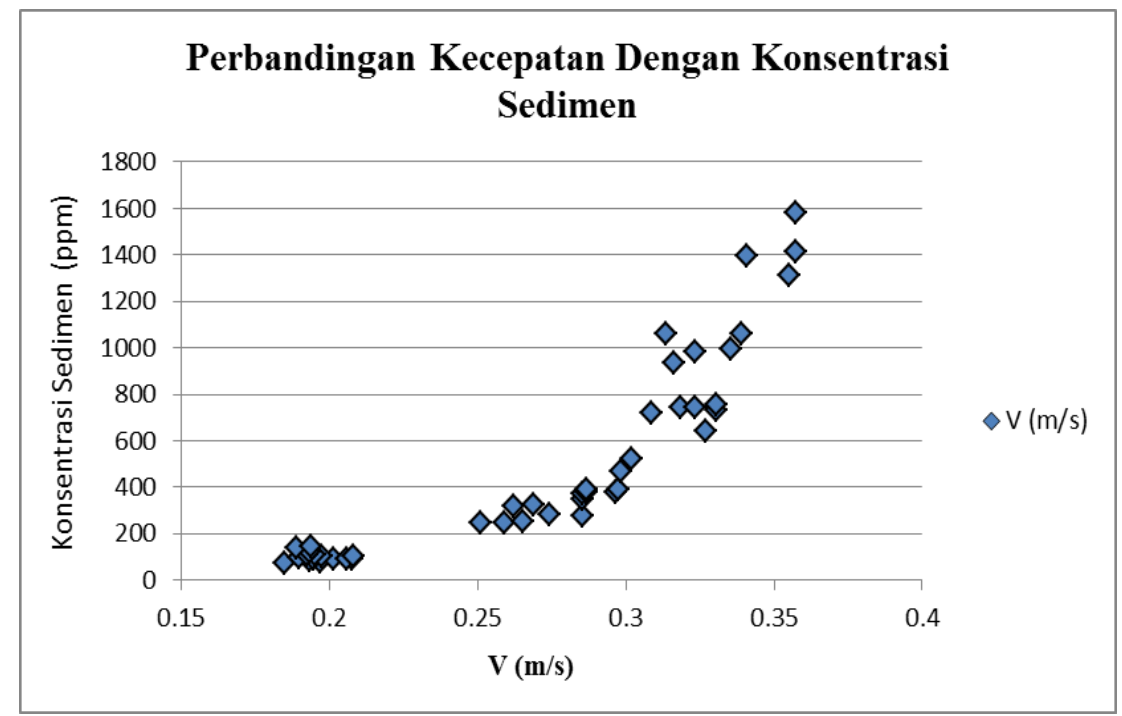

Gambar 2. Perbandingan kecepatan dengan konsentrasi sedimen

Hasil dari uji laboratorium akan dibandingkan dengan hasil perhitungan dari HEC-RAS. Pada HEC-RAS, dibuat penampang yang menyesuaikan flum yang digunakan pada laboratorium. Terdapat 3 sampel untuk pengujian angkutan sedimen. Pada tabel 5 sampai tabel 7 adalah hasil perbandingan angkutan sedimen pada HEC-RAS dan uji laboratorium:

Tabel 5. Hasil angkutan sedimen sampel 1

\begin{tabular}{cccccc}
\hline \multicolumn{7}{c}{ depth } & kondisi & Laboratorium & $\begin{array}{c}\text { Meyer-Peter } \\
\text { and Muller }\end{array}$ & $\begin{array}{c}\text { Engelund- } \\
\text { Hansen }\end{array}$ & Yang \\
\hline \multirow{2}{*}{0} & kecil & $1,3471 \mathrm{E}-03$ & $8,6642 \mathrm{E}-04$ & $1.72889 \mathrm{E}-07$ & $4.03407 \mathrm{E}-07$ \\
& sedang & $7,8153 \mathrm{E}-03$ & $1,0746 \mathrm{E}-02$ & $1.07941 \mathrm{E}-06$ & $6.6425 \mathrm{E}-07$ \\
& besar & $3,4590 \mathrm{E}-02$ & $3,5994 \mathrm{E}-02$ & $2.44622 \mathrm{E}-06$ & $2.49514 \mathrm{E}-06$ \\
\hline \multirow{4}{*}{-3} & kecil & $1,9987 \mathrm{E}-03$ & $6,0152 \mathrm{E}-04$ & $1.27376 \mathrm{E}-07$ & $2.3036 \mathrm{E}-07$ \\
& sedang & $9,4291 \mathrm{E}-03$ & $9,4236 \mathrm{E}-03$ & $9.48968 \mathrm{E}-07$ & $5.45152 \mathrm{E}-07$ \\
& besar & $3,9519 \mathrm{E}-02$ & $3,8362 \mathrm{E}-02$ & $2.72544 \mathrm{E}-06$ & $3.00048 \mathrm{E}-06$ \\
\hline \multirow{4}{*}{6} & kecil & $1,4777 \mathrm{E}-03$ & $9,8981 \mathrm{E}-04$ & $1.89262 \mathrm{E}-07$ & $4.80434 \mathrm{E}-07$ \\
& sedang & $1,1022 \mathrm{E}-02$ & $1,2960 \mathrm{E}-02$ & $1.1836 \mathrm{E}-06$ & $7.60889 \mathrm{E}-07$ \\
& besar & $3,2586 \mathrm{E}-02$ & $3,7861 \mathrm{E}-02$ & $2.6606 \mathrm{E}-06$ & $2.85952 \mathrm{E}-06$ \\
\hline \multirow{2}{*}{9} & kecil & $1,8164 \mathrm{E}-03$ & $5,0503 \mathrm{E}-04$ & $1.12288 \mathrm{E}-07$ & $1.84946 \mathrm{E}-07$ \\
& sedang & $7,4868 \mathrm{E}-03$ & $6,8106 \mathrm{E}-03$ & $7.51569 \mathrm{E}-07$ & $3.66149 \mathrm{E}-07$ \\
& besar & $1,4633 \mathrm{E}-02$ & $2,2662 \mathrm{E}-02$ & $1.76328 \mathrm{E}-06$ & $1.44269 \mathrm{E}-06$ \\
\hline \multirow{2}{*}{12} & kecil & $1,0599 \mathrm{E}-03$ & $6,7445 \mathrm{E}-04$ & $1.37648 \mathrm{E}-07$ & $2.75296 \mathrm{E}-07$ \\
& sedang & $5,3808 \mathrm{E}-03$ & $6,5980 \mathrm{E}-03$ & $7.28946 \mathrm{E}-07$ & $3.64473 \mathrm{E}-07$ \\
& besar & $1,7518 \mathrm{E}-02$ & $2,4274 \mathrm{E}-02$ & $1.85013 \mathrm{E}-06$ & $1.57261 \mathrm{E}-06$ \\
\hline
\end{tabular}


Tabel 6. Hasil angkutan sedimen sampel 2

\begin{tabular}{|c|c|c|c|c|c|}
\hline \multicolumn{6}{|c|}{ Angkutan Sedimen Sampel 2 (kg/m.s) } \\
\hline depth & kondisi & Laboratorium & $\begin{array}{l}\text { Meyer-Peter } \\
\text { and Muller }\end{array}$ & $\begin{array}{c}\text { Engelund- } \\
\text { Hansen }\end{array}$ & Yang \\
\hline \multirow{3}{*}{0} & kecil & $1,4506 \mathrm{E}-03$ & $6,8706 \mathrm{E}-04$ & $1.38152 \mathrm{E}-07$ & $2.76304 \mathrm{E}-07$ \\
\hline & sedang & $7,5792 \mathrm{E}-03$ & $9,0607 \mathrm{E}-03$ & $9.2356 \mathrm{E}-07$ & 5.22012E-07 \\
\hline & besar & $4,2835 \mathrm{E}-02$ & $3,0309 \mathrm{E}-02$ & $2.17217 \mathrm{E}-06$ & 2.02895E-06 \\
\hline \multirow{3}{*}{-3} & kecil & $1,2048 \mathrm{E}-03$ & $6,2441 \mathrm{E}-04$ & $1.30691 \mathrm{E}-07$ & $2.45045 \mathrm{E}-07$ \\
\hline & sedang & $5,5570 \mathrm{E}-03$ & $8,7856 \mathrm{E}-03$ & 8.99514E-07 & 4.9973E-07 \\
\hline & besar & $1,7571 \mathrm{E}-02$ & $2,8660 \mathrm{E}-02$ & $2.08393 \mathrm{E}-06$ & $1.91816 \mathrm{E}-06$ \\
\hline \multirow{3}{*}{-6} & kecil & $1,1643 \mathrm{E}-03$ & $6,0097 \mathrm{E}-04$ & $1.27257 \mathrm{E}-07$ & $2.30146 \mathrm{E}-07$ \\
\hline & sedang & 4,7031E-03 & $5,2129 \mathrm{E}-03$ & $6.12242 \mathrm{E}-07$ & 4.45267E-07 \\
\hline & besar & $1,5555 \mathrm{E}-02$ & $1,5027 \mathrm{E}-02$ & $1.31695 \mathrm{E}-06$ & $9.06755 \mathrm{E}-07$ \\
\hline \multirow{3}{*}{-9} & kecil & $1,4593 \mathrm{E}-03$ & 5,7299E-04 & $1.23738 \mathrm{E}-07$ & $2.15197 \mathrm{E}-07$ \\
\hline & sedang & $6,8921 \mathrm{E}-03$ & $5,1359 \mathrm{E}-03$ & $6.10579 \mathrm{E}-07$ & 4.44058E-07 \\
\hline & besar & 2,3292E-02 & $1,6824 \mathrm{E}-02$ & $1.42624 \mathrm{E}-06$ & $1.03128 \mathrm{E}-06$ \\
\hline \multirow{3}{*}{-12} & kecil & $1,4552 \mathrm{E}-03$ & $6,3699 \mathrm{E}-04$ & $1.32541 \mathrm{E}-07$ & $2.45952 \mathrm{E}-07$ \\
\hline & sedang & $6,4859 \mathrm{E}-03$ & $5,5096 \mathrm{E}-03$ & $6.35508 \mathrm{E}-07$ & $4.67285 \mathrm{E}-07$ \\
\hline & besar & $2,0748 \mathrm{E}-02$ & $1,7865 \mathrm{E}-02$ & $1.48279 \mathrm{E}-06$ & $1.10656 \mathrm{E}-06$ \\
\hline
\end{tabular}

Tabel 7. Hasil angkutan sedimen sampel 3

\begin{tabular}{cccccc}
\hline \multicolumn{5}{c}{ Angkutan Sedimen Sampel 3 $(\mathrm{kg} / \mathrm{m} . \mathrm{s})$} \\
\hline \multirow{2}{*}{ depth } & kondisi & Laboratorium & $\begin{array}{c}\text { Meyer-Peter } \\
\text { and Muller }\end{array}$ & $\begin{array}{c}\text { Engelund- } \\
\text { Hansen }\end{array}$ & Yang \\
\hline \multirow{2}{*}{0} & kecil & $1,6110 \mathrm{E}-03$ & $6,0097 \mathrm{E}-04$ & $1.27257 \mathrm{E}-07$ & $2.30146 \mathrm{E}-07$ \\
& sedang & $6,9597 \mathrm{E}-03$ & $4,1736 \mathrm{E}-03$ & $5.20857 \mathrm{E}-07$ & $4.31054 \mathrm{E}-07$ \\
& besar & $2,1991 \mathrm{E}-02$ & $1,7510 \mathrm{E}-02$ & $1.4565 \mathrm{E}-06$ & $1.08134 \mathrm{E}-06$ \\
\hline \multirow{4}{*}{3} & kecil & $1,3020 \mathrm{E}-03$ & $5,2525 \mathrm{E}-04$ & $1.15588 \mathrm{E}-07$ & $1.86004 \mathrm{E}-07$ \\
& sedang & $4,4798 \mathrm{E}-03$ & $4,4562 \mathrm{E}-03$ & $5.4411 \mathrm{E}-07$ & $4.17151 \mathrm{E}-07$ \\
& besar & $1,7310 \mathrm{E}-02$ & $2,5791 \mathrm{E}-02$ & $1.93624 \mathrm{E}-06$ & $1.67963 \mathrm{E}-06$ \\
\hline \multirow{4}{*}{6} & kecil & $9,3766 \mathrm{E}-04$ & $4,3899 \mathrm{E}-04$ & $1.00879 \mathrm{E}-07$ & $1.42265 \mathrm{E}-07$ \\
& sedang & $5,6241 \mathrm{E}-03$ & $3,7115 \mathrm{E}-03$ & $4.76771 \mathrm{E}-07$ & $3.8848 \mathrm{E}-07$ \\
& besar & $2,1535 \mathrm{E}-02$ & $1,6757 \mathrm{E}-02$ & $1.42542 \mathrm{E}-06$ & $1.03069 \mathrm{E}-06$ \\
\hline \multirow{2}{*}{9} & kecil & $1,3007 \mathrm{E}-03$ & $9,7319 \mathrm{E}-04$ & $1.74401 \mathrm{E}-07$ & $3.92402 \mathrm{E}-07$ \\
& sedang & $6,5096 \mathrm{E}-03$ & $9,5059 \mathrm{E}-03$ & $9.50152 \mathrm{E}-07$ & $6.46912 \mathrm{E}-07$ \\
& besar & $2,5154 \mathrm{E}-02$ & $2,8975 \mathrm{E}-02$ & $2.11097 \mathrm{E}-06$ & $1.94494 \mathrm{E}-06$ \\
\hline \multirow{2}{*}{-12} & kecil & $1,3106 \mathrm{E}-03$ & $7,8951 \mathrm{E}-04$ & $1.55016 \mathrm{E}-07$ & $2.39571 \mathrm{E}-07$ \\
& sedang & $4,6852 \mathrm{E}-03$ & $6,1051 \mathrm{E}-03$ & $6.8287 \mathrm{E}-07$ & $4.55246 \mathrm{E}-07$ \\
& besar & $1,6915 \mathrm{E}-02$ & $2,4367 \mathrm{E}-02$ & $1.85114 \mathrm{E}-06$ & $1.57347 \mathrm{E}-06$ \\
\hline
\end{tabular}


Dari gambar 3, terlihat bahwa debit air mempengaruhi hasil angkutan sedimen yang didapat, hal ini dibuktikan dengan kenaikkan grafik yang konstan sesuai dengan debit air. Semakin besar kenaikkan debit air, maka hasil angkutan sedimen yang didapat semakin besar

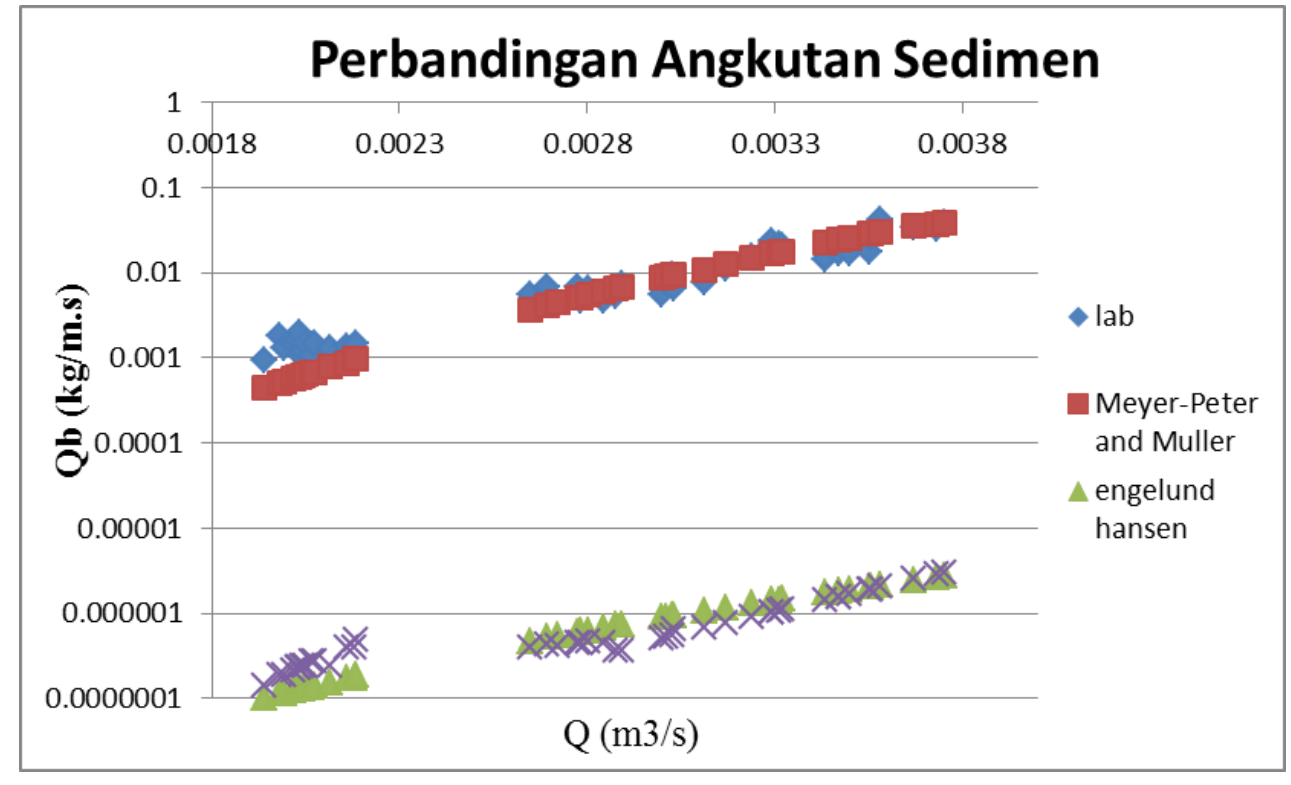

Gambar 3. Grafik perbandingan hasil angkutan sedimen

\section{KESIMPULAN DAN SARAN}

Kesimpulan pada pengujian angkutan sedimen Sungai Cibeet adalah sebagai berikut:

1. Hasil angkutan sedimen yang didapat pada pengujian pada 3 sampel secara laboratorium berkisar antara 9,3766E-04 Kg/m.s hingga 4,2834E-02 Kg/m.s dengan debit air antara 1,94E-03 m³ $/ \mathrm{s}$ hingga 3,581E-03 m³. Semakin besar kecepatan maka debit air semakin besar, dan angkutan sedimen yang dibawa akan semakin banyak.

2. Pada perhitungan dengan program HEC-RAS, metode Meyer-Peter and Muller mendapatkan hasil angkutan sedimen antara 4,38992E-04 Kg/m.s hingga 3,8361662E-02 Kg/m.s. Metode Engelund-Hansen mendapat hasil angkutan sedimen antara $1.00879 \mathrm{E}-07 \mathrm{Kg} / \mathrm{m} . \mathrm{s}$ hingga $2.72544 \mathrm{E}-06 \mathrm{Kg} / \mathrm{m} . \mathrm{s}$. Metode Yang mendapat hasil angkutan sedimen antara $1.42265 \mathrm{E}-07 \mathrm{Kg} / \mathrm{m} . \mathrm{s}$ hingga $3.00048 \mathrm{E}-06 \mathrm{Kg} / \mathrm{m} . \mathrm{s}$.

3. Dari hasil perbandingan angkutan sedimen yang telah didapat, metode Meyer-Peter and Muller memiliki hasil yang paling mendekati dengan pengujian laboratorium. Pada debit kecil (rata-rata $0.00206 \mathrm{~m} 3 / \mathrm{s}$ ) didapat persentase rata-rata sebesar $50.25 \%$. Pada debit sedang (rata-rata $0.00289 \mathrm{~m} 3 / \mathrm{s}$ ) didapat persentase rata-rata sebesar $24.45 \%$. Pada debit besar (rata-rata $0.00348 \mathrm{~m} 3 / \mathrm{s}$ ) didapat persentase rata-rata sebesar $26.99 \%$.

4. Perbedaan hasil angkutan sedimen pada pengujian laboratorium dan metode Meyer-Peter and Muller dikarenakan beberapa alasan, yaitu pada pengujian laboratorium, sedimen tidak memenuhi dasar saluran, sehingga kemungkinan hasil yang didapat berbeda. Lalu karena adanya asumsi kemiringan pada saluran, dapat menyebabkan hasil angkutan sedimen berbeda, dikarenakan pada flume tidak ada kemiringan dasar saluran. Pada kasus metode Engelund-Hansen, hasil yang didapat berbeda karena metode ini hanya digunakan pada sedimen dasar dengan bentuk gundukan atau dune bedload. Terbatasnya gradasi butiran pada metode ini juga menyebabkan ketidakakuratan untuk hasil yang didapat. Pada metode Yang, hasil yang didapat berbeda karena rumus yang digunakan merupakan rumus pada penelitian lapangan, dimana kecepatan aliran dan ukuran penampang sudah disesuaikan dengan penelitian sampel Yang. 
Saran untuk penelitian selanjutnya adalah sebagai berikut:

1. Diperlukan pemahaman lebih lanjut dalam mengolah program HEC-RAS, terutama dalam penelitian sedimen dan pemakaian metode lainnya. Lalu dibutuhkan penampang dan alur sungai yang asli agar hasil yang didapat lebih akurat, dikarenakan ada beberapa metode yang memakai perhitungan sesuai kondisi lapangan.

2. Untuk percobaan laboratorium, sedimen yang digunakan lebih bervariasi seperti penelitian total bed load transport, sedimen melayang pada Sungai Cibeet, dan lokasi pengambilan sampel lebih beragam seperti pada hulu dan tengah sungai.

\section{DAFTAR PUSTAKA}

Brunner, Gary.W and Stanford Gibson. "Sediment Transport Modeling in HEC-RAS.” ASCE (2005).

Brunner, Gary.W. HEC-RAS, River Analysis System Hydraulic Reference Manual. Davis: US Army Corps of Engineers, 2016.

Sandjaja, Gregorius.S and Aniek Prihatiningsih. Petunjuk Praktikum Mekanika Tanah. Jakarta: Jurusan Teknik Sipil Universitas Tarumanagara, 2015.

Yang, Chih Ted. Sediment Transport Theory and Practice. United States of America: The McGraw-Hill Companies, 1996. 